УДК 351.82:334.7] (477)

DOI: $10.34132 /$ pard2020.07.12

\title{
ДЕРЖАВНО-ПРИВАТНЕ ПАРТНЕРСТВО ЯК ВАЖЛИВИЙ ІНСТРУМЕНТ ЗАБЕЗПЕЧЕННЯ СТАЛОГО РОЗВИТКУ ТЕРИТОРІЙ
}

Хаджсирадєва $\boldsymbol{C . K . , ~ д - р ~ н а у к ~ з ~ д е р ж . ~ у п р . , ~ п р о ф е с о р , ~ Н а ц і о н а л ь - ~}$ на академія державного управління при Президентові України, м. Київ, Україна

Васильєва Н.В., д-р наук 3 держ. упр., професор, Національна академія державного управління при Президентові України, м. Київ, Україна

Васильєва O.I., д-р наук 3 держ. упр., професор, Національна академія державного управління при Президентові України, м. Київ, Україна

Киртока M., аспірант, Національна академія державного управління при Президентові України, м. Київ, Україна

У статті зазначено, щзо з 2015 року перед міжнародною спільнотою постали нові амбітні завдання щзодо досягнення иілей сталого розвитку, визначених схваленою на черговому саміті Організації Об 'єднаних Націй Стратегією “Перетворення нашого світу: Порядок денний у сфері сталого розвитку до 2030 року”. Майже всі вони передбачають необхідність створення або модернізації економічної та соиіальної інфраструктури в країнах, які розвиваються, щзо потребує значних фінансових ресурсів. Однак, бюджети таких краӥн не можуть покрити наявні фінансові потреби. Тому, одним із найважливіших завдань нової глобальної стратегї сталого розвитку було визнано створення умов для залучення фінансових ресурсів приватного сектору для розбудови інфраструктури на засадах публічно-приватного партнерства (ППП). Зауважено, щуо основне 
завдання органів публічної влади сьогодні полягає у формуванні сприятливого середовища для ведення бізнесу, ефективного використання ресурсного потенціалу, визначенні пріоритетів в сочіальних, економічних та екологічних прочесах $i$ перспектив розвитку територіальної громади з врахуванням ї̈ потреб й інтересів.

Акиентовано увагу на тому, щуо у світі дедалі більше стає популярним державно-приватне партнерство у формі концесії, оскільки саме така форма взаємодї між приватним та публічним партнером створює суттєву додану вартість для обох сторін. Одне $з$ найбільших досягнень концесій - завдяки їй вирішуються державні завдання силами приватного капіталу, який вважається економічно ефективнішим держсавного. При ицьому, приватний партнер отримує довгостроковий фінансовий інтерес, який дозволяє йому забезпечити максимальну ефективність вирімення поставленого державою чи муніциипалітетом завдання. Обгрунтовано доцільність застосування державно-приватного партнерства при формуванні інструменту забезпечення сталого розвитку територій як важливого інструменту забезпечення сталого розвитку територій.

Ключові слова: державно-приватне партнерство, органи публічної влади, концесія, сталий розвиток територій.

Постановка проблеми у загальному вигляді. Державна політика щодо досягнення сталого розвитку передбачає послідовну реалізацію комплексу управлінських, економічних, організаційних, фінансових заходів на всіх рівнях влади. Основне завдання органів публічної влади полягає у формуванні сприятливого середовища для ведення бізнесу, ефективного використання ресурсного потенціалу, визначенні пріоритетів в соціальних, економічних та екологічних процесах і перспектив розвитку територіальної громади 3 врахуванням iï потреб й інтересів [7, с. 77].

В цих відносинах дуже важливою $є$ функціонування системи регіонального партнерства бізнесу і влади які значною мірою залежать від наявності необхідних умов, до яких відносимо: сформованість сторін партнерства бізнесу і влади, наявність нормативно-правової бази, створення органів партнерства бізнесу і влади тощо [8, с. 90]. 
32015 р. перед міжнародною спільнотою постали нові амбітні завдання щодо досягнення цілей сталого розвитку, визначених схваленою на черговому саміті Організації Об'єднаних Націй Стратегією «Перетворення нашого світу: Порядок денний у сфері сталого розвитку до 2030 року». Майже всі цілі сталого розвитку передбачають необхідність створення або модернізації економічної та соціальної інфраструктури в країнах, які розвиваються, що, своєю чергою, потребує значних фінансових ресурсів. Зважаючи на те, що бюджети таких країн не можуть покрити наявні фінансові потреби, одним із найважливіших завдань нової глобальної стратегії сталого розвитку було визнано створення умов для залучення фінансових ресурсів приватного сектору для розбудови інфраструктури на засадах публічно-приватного партнерства (ППП).

У світі дедалі більше стає популярним державно-приватне партнерство (ДПП) у формі концесії, оскільки саме така форма взаємодії між приватним та публічним партнером створює суттєву додану вартість для обох сторін. Одне 3 найбільших досягнень концесій - завдяки їй вирішуються державні завдання силами приватного капіталу, який вважається економічно ефективнішим державного. При цьому, приватний партнер отримує довгостроковий фінансовий інтерес, який дозволяє йому забезпечити максимальну ефективність вирішення поставленого державою чи муніципалітетом завдання.

За даними Міністерства розвитку економіки, торгівлі та сільського господарства України на 01.01.2020 р. в Україні на засадах державно-приватного партнерства (ДПП) було укладено 187 договорів, з них зокрема реалізуються всього 52 договори, у т.ч. у формі концесії - 35. Проте, жодного масштабного проекту на умовах концесії в Україні не було реалізовано.

\section{Аналіз останніх досліджень і публікацій.}

У науковій літературі дослідженню проблем публічного управління застосування програмно-цільового та сервісного підходів до сталого розвитку територій присвячено праці М. Бриль, З. Бурик, В. Вакуленка, Н.Васильєвої, О. Свсюкової, Т. Іванової, В. Савенка, А. Ткачука та інших дослідників. 
Основні напрями формування системи державно-приватного партнерства, визначення особливостей інвестиційного забезпечення територій досліджували М.Авксєнтьєв, В.Вайсман, О.Вікарчук, В.Геєць, І.Дахно, Н.Дутко, В. Смельянов, Л.Гончарук, О.Зельдіна, I.Крейдич, Д.Ляпін, В.Мотриченко, В.Мунтіян, А.Овчинніков, С.Сімак, О.Цогла та ін.

Аналіз правового забезпечення державно-приватного партнерства відобразили в роботах науковці С.Алєксєєв, М.Біль, О.Крайник, В.Марущак, Н.Мєдвєдєва, Ю.Оборотов, Г.Третяк, К.Шундиков, О.Юрченко та ін.

Питання необхідності модернізації інфраструктурних галузей України розглядали в наукових роботах Б.Данилишин, М.Погребняк, І.Розпутенко, М.Скринько та ін.

Формулювання цілей статті (постановка завдання). Водночас, незважаючи на значну увагу науковців до означеної проблематики та високий рівень іiі дослідження, питання доцільності застосування державно-приватного партнерства при формуванні інструменту забезпечення сталого розвитку територій як пріоритетного напряму реалізації державної регіональної політики, залишаються актуальними та своєчасними. Потреба у вирішенні зазначених проблемних питань на науковому та практичному рівнях обумовили вибір теми та підкреслює її актуальність. Мета дослідження полягає в обгрунтовані доцільності застосування державно-публічного партнерства при формуванні інструменту забезпечення сталого розвитку територій як пріоритетного напряму реалізації державної регіональної політики.

Виклад основного матеріалу дослідження. Основними причинами відсутності позитивного досвіду реалізації концесійних проектів в країні $є$ те, що державне регулювання державно-приватного партнерства, у тому числі концесійної діяльності (ДРКД) в Україні має недоліки та прогалини. Так, рішення щодо доцільності реалізації концесійних проектів приймалися без проведення ретельних аналізів, що використовуються в міжнародній практиці, зокрема це стосується аналізу ефективності здійснення ДПП як передумови виникнення концесійних відносин. 
Історично так склалося, що концесія не $\epsilon$ абсолютно ексклюзивною формою господарювання. Різні види концесії існують, можливо десь стільки ж, скільки існує держава. Зазначене зумовлене тим, що в різні часи держави були вимушені делегувати управління своєю власністю окремим суб'єктам господарювання, при цьому, обов'язково залишаючись власником об'єкту концесії. Так, концесії на освоєння та розробку корисних копалин були надані в Іспанії в 1256 р., в Італії - на видобуток нафти - в 1400 р. У Франції перша концесія була надана в XVI ст. королем Генріхом II при реалізації проекту спорудження та експлуатації штучного каналу біля міста Салон-де-Прованс.

Взаємодія держави та приватних осіб в XIX-XX ст.ст. дозволила втілити надзвичайні проекти та створити безліч об'єктів інфраструктури, таких як Суецький канал (1869р.), який фактично змінив карту світового мореплавства, Панамський канал (1914 р.) та Ейфелева вежа (1889 р.). При цьому, варто відзначити, що для залучення коштів, яких не вистачало для завершення побудови Ейфелевої вежі було створено акціонерне товариство зі статутним фондом 5 млн. франків. Видатки на будівництво окупились протягом першого року, а інженер А.Г. Ейфель, який підписав концесію з урядом Франції та муніципалітетом Парижу, в результаті реалізації проекту став доволі багатою людиною [2, с. 73].

Концесія розглядається сьогодні як складне багатовимірне поняття, виступаючи одночасно і системою взаємовідносин суб'єктів державно-владних відносин та приватного сектору; і як владний публічний акт; і безпосередньо як об’єкти, що передаються в концесію; і як договір з передачі об'єктів державної чи комунальної власності, а також як спеціальний режим господарювання. Концесійна модель управління передбачає усунення державного партнера від проблем прямого управління будівництвом чи користуванням об'єктом концесії, за умови передачі концесіонерові майнової відповідальності, підприємницького ризику тощо. Отже, по суті, приватний партнер (концесіонер) отримує право здійснення концесійної діяльності разом 3 делегованими йому від державного партнера (концесієдавця) частини економічних, організаційних і управлінських функцій в пу- 
блічному секторі, який, в свою чергу, зберігає за собою адміністративно-контрольні повноваження.

Закон України «Про концесію» від 03.10.2019 р. передбачає створення віртуальної кімнати даних - захищеного відповідно до законодавства інтернет-ресурсу, на якому має бути розміщено інформацію про об' єкт концесії, балансоутримувача (його фінансовий стан), документи та відомості, необхідні для отримання дозволу на концентрацію, інші відомості, у тому числі інформація з обмеженим доступом (крім таємної та службової інформації), а також інша інформація, визначена концесієдавцем за пропозицією радника (у разі його залучення) [3]. При цьому, варто відмітити, що систематизацію документів та підготовка віртуальної кімнати даних законодавець відніс до основних завдань радника - фізичної та/або юридичної особи, яка за цивільним договором бере на себе зобов'язання надавати послуги при підготовці проекту, що здійснюється на умовах концесії. Крім того, відповідно до п.4 ч.6 статті 13 Закон України «Про концесію» від 03.10.2019 р. зазначена віртуальна кімната даних може і не створюватись [3].

Основною метою державного регулювання концесійної діяльності вважаємо упорядкування відносин між державою/органом місцевого самоврядування та юридичною особою - резидентом України задля ефективного управління об'єктами концесії в частині модернізації інфраструктури та підвищення якості суспільно значущих послуг. Це, в свою чергу, спонукає на здійснення системного аналізу механізмів реалізації концесійної діяльності, додержуючись структурно-функціонального підходу та акцентуючи увагу не тільки на організаційній основі його побудови, але і на його динаміці, реальному функціонуванні, сукупності універсальних та спеціальних методів та прийомів.

Отже, функціонування всіх механізмів у комплексній системі повинно бути спрямованим на відповідність цілям і поставленим завданням, їх узгодженість і взаємозв'язок між собою та окремими структурними їх елементами. Тому, суб' єктам публічного управління слід постійно проводити моніторингові дослідження внутрішніх і зовнішніх факторів, вчасно виявляти проблеми, підходити до при- 
йняття управлінських рішень на основі системного підходу, використання сукупності наукових і спеціальних методів з урахуванням змін внутрішнього та зовнішнього середовища [7; 5 с. 154].

Таким чином, реалізація концесійної діяльності в міському господарстві визначається нами як сукупність цілей, принципів, функцій, форм, методів, інструментів і способу їх застосування органами державної влади й органами місцевого самоврядування для забезпечення підтримки та розвитку концесії, активізації інвестиційних та інноваційних процесів, з метою сталого розвитку населених пунктів та економіко-соціальної ефективності від концесії.

Отже, ДРКД - це опосередковане управління системою правовідносин між суб'єктами концесійної діяльності, які виникають у зв'язку з реалізацією проектів, що здійснюються на умовах концеciї, через систему заходів законодавчого, виконавчого, наглядового та контролюючого характеру, здійснюваних суб'єктами владних повноважень на різних рівнях, з метою забезпечення ефективного функціонування об'єктів концесії.

Здійснюючи порівняльний аналіз переліку об'єктів права державної чи комунальної власності, які надавались в концесію відповідно до Закону України «Про концесії» від 16.07.1999 р. (втратив чинність) та об'єктів концесії згідно з Законом України «Про концесію» від 03.10.2019 р., відмічаємо, що чинний Закон України «Про концесію» від 03.10.2019 р., на відміну від попереднього концесійного закону, визначив термін «об’єкт концесії», сутність якого не включає розподіл за критерієм забезпечення завершального циклу виробництва, а саме: цілісний майновий комплекс, система цілісних майнових комплексів, об’єкти незавершеного будівництва та законсервовані об'єкти, проте акцентує увагу на власність майна, а саме державне майно, майно АРК, комунальне майно, майно господарських товариств, 100 відсотків акцій (часток) яких належать державі, Автономній Республіці Крим, територіальній громаді або іншому господарському товариству, 100 відсотків акцій (часток) якого належать державі.

Вказаний підхід законодавця спрощує розуміння потенційного об’єкту концесії та не потребує додаткових роз'яснень Міністерства 
розвитку громад та територій України. Проте, наприклад виконавчому комітету Одеської міської ради, під час організаційно-технічної підготовки частини магістральної системи водовідведення Південного басейну каналізування м. Одеси до передачі в концесію, все ж довелось звертатись листом від 29.02.2016 р. № 02.2-16вих/120 до тодішнього Міністерства регіонального розвитку, будівництва та житлово-комунального господарства України з питанням щодо можливості віднесення вказаного об'єкту до цілісного майнового комплексу або структурного підрозділу, який використовується у сфері водовідведення, що перебуває у комунальній власності та використовується для забезпечення завершеного циклу виробництва продукції (робіт, послуг) у сферах діяльності, що визначені частинами другою, третьою та четвертою статті 3 Закону України «Про концесії» від 16.07.1999 р. При цьому, цікавим залишається той факт, що Методика розрахунку концесійних платежів, яка затверджена Постановою Кабінету Міністрів України від 12 квітня 2000 р. № 639 в редакції від 14.11.2019 р. продовжує визначати способи розрахунку концесійного платежу за право на управління (експлуатацію) майном підприємств, їх структурних підрозділів, що є цілісними майновими комплексами або їх системою, забезпечує завершений цикл виробництва продукції (робіт, послуг) та добудову об’єкта незавершеного будівництва [4]. Крім того, положення Податкового кодексу України також акцентують увагу на концесію цілісного майнового комплексу державного або комунального підприємства в частині погашення грошових зобов'язань чи податкового боргу з боку платника податків - концесіонера після прийняття вказаного майна в концесію.

Що ж до практичного положення, розглянемо ситуацію, яка склалась у місті Одесі з об’єктами концесії у сфері водовідведення на підставі аналізу, проведеного департаментом аналітики та контролю Одеської міської ради. Так, у місті Одесі, в рамках спільно реалізованого Світовим Банком та тодішнім Міністерством регіонального розвитку, будівництва та житлово-комунального господарства України проекту під назвою «Розвиток міської інфраструктури в Україні» комунальним підприємством «Агентство програм розвитку Одеси» (КП «АПРО») отримано кошти на будівництво та оснащення новим 
обладнанням КНС№ 6Б та КНС№ 7А, будівництво між ними напірного колектора та реконструкцію тунелю глибокого закладення, технічне переоснащення КНС № 8 та реконструкцію Ствола № 1 [6].

Рішенням Одеської міської ради від 29.10.2014 р. № 5578-VI (зі змінами від 10.09.2015 р. № 6967-VI) було погоджено пропозицію виконавчого комітету Одеської міської ради про передачу в концесію частини магістральної системи водовідведення Південного басейну каналізування міста Одеси та затверджено Перелік майна, що входить до складу каналізаційних насосних станцій КНС №6Б та КНСo 7А (надалі - Об’єкти). Рішенням Одеської міської ради від 08.11.2017 р. № 2603-VII термін здійснення організаційно-технічної підготовки частини магістральної системи водовідведення Південного басейну каналізування м. Одеси до передачі в концесію продовжений до 01.04.2018 p.

3 метою проведення організаційно-технічної підготовки частини магістральної системи водовідведення Південного басейну каналізування м. Одеси для передачі в концесію за період 2017 - 2018 рр. були проведені наступні заходи:

- КП «АПРО» була проведена інвентаризація коштів і товарно-матеріальних цінностей Об'єктів, про що був складений акт від 30.06.2017 p.;

- отримано державні акти на право постійного користування КП «АПРО» земельними ділянками за адресами: м. Одеса, вул. Алмазна, 36; м. Одеса, пров. Кордонний, 3-Г;

- зареєстровано право господарського відання на КНС № 7А i КНС № 6Б (відповідно до рішення виконавчого комітету Одеської міської ради від 04 жовтня 2017 року № 365 «Про реєстрацію права комунальної власності територіальної громади м. Одеси в особі Одеської міської ради на каналізаційні насосні станції, розташовані в Одесі, і закріплення такого майна за комунальним підприємством «Агентство програм розвитку Одеси» на правах господарського відання»).

При цьому, з міського бюджету здійснюється погашення валютного кредиту, отриманого підприємством в рамках Угоди про позику між Міжнародним банком реконструкції та розвитку і Україною від 
26.05.2008 р. №4869-UA в рамках Договору гарантії між Україною в особі Міністерства фінансів України й Одеською міською радою від 18.12.2007 p. №28000- 04/213 і відсотків по ньому (виконання зобов’язань за проектом «Розвиток міської інфраструктури в Україні»). Загальна сума кредитних коштів, отриманих КП «АПРО» - 45008 362,4 дол. США. Термін повернення кредитних коштів - 3 квітня 2013 року по жовтень 2027 року. Рішенням Одеської міської ради від 11.12.2019 p. № 5453-VII установлено, що у бюджеті міста Одеси на 2020 рік враховані витрати на надання фінансової підтримки КП «АПРО» в сумі 97918300 гривень для забезпечення виконання зобов'язань по проекту «Розвиток міської інфраструктури в Україні» «закритий та відкритий компоненти» (головний розпорядник бюджетних коштів департамент міського господарства Одеської міської ради) [1].

3 огляду на вищевикладене, головними проблемами $є$ питання, пов'язані з вибором варіанту правових відносин між балансоутримувачем КП «АПРО» та приватним партнером, який буде експлуатувати і обслуговувати вказані Об' єкти. Що ж до практичного положення, розглянемо ситуацію, яка склалась у місті Одесі з об'єктами концесії у сфері водовідведення на підставі аналізу, проведеного департаментом аналітики та контролю Одеської міської ради. Так, у місті Одесі, в рамках спільно реалізованого Світовим Банком та тодішнім Міністерство регіонального розвитку, будівництва та житлово-комунального господарства України проекту під назвою «Розвиток міської інфраструктури» комунальним підприємством «Агентство програм розвитку Одеси» (КП «АПРО») отримано кошти на будівництво та оснащення новим обладнанням КНС№ 6Б та КНСo 7А, будівництво між ними напірного колектора та реконструкцію тунелю глибокого закладення, технічне переоснащення КНС № 8 та реконструкцію Ствола № 1 [1].

Рішенням Одеської міської ради від 29.10.2014 р. № 5578-VI (зі змінами від 10.09.2015 р. № 6967-VI) було погоджено пропозицію виконавчого комітету Одеської міської ради про передачу в концесію частини магістральної системи водовідведення Південного басейну каналізування міста Одеси та затверджено Перелік майна, що входить до складу каналізаційних насосних станцій КНС № 6Б, розташованої 
за адресою: м. Одеса, вул. Алмазна, 36 та КНС№ 7А, розташованої за адресою: м. Одеса, пров. Кордонний, 3-Г (надалі - Об'єкти).

Рішенням Одеської міської ради від 08.11.2017 р. № 2603-VII термін здійснення організаційно-технічної підготовки частини магістральної системи водовідведення Південного басейну каналізування м. Одеси до передачі в концесію продовжений до 01.04.2018 р.

При цьому, з міського бюджету здійснюється погашення валютного кредиту, отриманого підприємством в рамках Угоди про позику між Міжнародним банком реконструкції та розвитку і Україною від 26.05.2008 р. №4869-UА в рамках Договору гарантії між Україною в особі Міністерства фінансів України й

Одеською міською радою від 18.12.2007 р. №28000- 04/213 і відсотків по ньому (виконання зобов'язань за проектом «Розвиток міської інфраструктури в Україні»). Загальна сума кредитних коштів, отриманих КП «АПРО» - 45008 362,4 дол. США. Термін повернення кредитних коштів - 3 квітня 2013 року по жовтень 2027 року. Рішенням Одеської міської ради від 11.12.2019 р. № 5453-VII установлено, що у бюджеті міста Одеси на 2020 рік враховані витрати на надання фінансової підтримки КП «АПРО» в сумі 97918300 гривень для забезпечення виконання зобов'язань по проекту «Розвиток міської інфраструктури в Україні» «закритий та відкритий компоненти» (головний розпорядник бюджетних коштів - департамент міського господарства Одеської міської ради) [1].

3 огляду на вищевикладене, головними проблемами є питання, пов'язані з вибором варіанту правових відносин між балансоутримувачем КП «АПРО» та приватним партнером, який буде експлуатувати і обслуговувати вказані Об'єкти.

Отже, за результатами підготовки до проведення аналізу ефективності здійснення ДПП та, розглянувши пропозицію виконавчого комітету Одеської міської ради щодо передачі частини магістральної системи водовідведення Південного басейну каналізування м. Одеси в концесію, з метою раціонального використання бюджетних коштів та забезпечення ефективності функціонування об'єктів комунальної власності територіальної громади міста Одеси Одеська міська рада своїм рішенням від 20.03.2019 р. №4368-VII погодила 
пропозицію передачі частини магістральної системи водовідведення Південного басейну каналізування м. Одеси в оренду. Зазначене рішення було прийнято у тому числі й з огляду на затвердження рішенням Одеської міської ради № 4214-VII від 30.01.2019 р. Методики розрахунку орендної плати за майно комунальної власності територіальної громади м. Одеси, в якій орендна ставки за використання цілісних майнових комплексів комунальної власності територіальної громади міста Одеси у сфері водовідведення складає 1 \% [1].

Отже, не зважаючи на двадцятирічне існування концесійного законодавства в Україні, органи управління державним чи комунальним майном продовжують застосовувати більш звичну та просту у впровадженні форму взаємодії з приватним сектором - оренду 3 усіма притаманними їй ризиками, у т.ч. пов'язаними з розрахунком концесійних платежів та плати, яка повинна сплачуватись публічному партнерові.

Висновки. Отже, не дивлячись на кардинально новий підхід законодавця у Законі України «Про концесію» від 03.10.2019 р. стосовно «об’єкту концесії», чинний концесійний закон не містить визначення пріоритетних сфер, в яких визнається доцільною передача об'єктів в концесію; не встановлює достатніх обмежень щодо об'єктів, які можуть бути передані в концесію та зовсім не узгоджується 3 «Триажем» щодо залишення в державній власності об'єктів загальнодержавного значення та які відповідають встановленим критеріям відбору, що виконують стратегічно важливі функції не лише в оборонній та правоохоронній сферах, але і в сферах охорони здоров'я та навколишнього середовища; стандартизації, метрології та реєстрів; соціальної політики, культури, спорту та освіти; об’єкти, необхідні, для виконання державою своїх основних функцій та тим самим не залишає в держави інструменти для виконання своїх основних функцій, що безумовно потребує суттєвого доопрацювання.

При цьому, прийняття рішення про здійснення концесії повинне пройти доволі складні погоджувальні процедури, які потребують кропіткої аналітичної роботи від відповідальних виконавців. Особливої уваги під час реалізації концесійної діяльності заслуговує 
аналіз ефективності здійснення ДПП, як передумова виникнення концесійних відносин.

Зауважено, що відповідно до Закону України «Про концесію» від 03.10.2019 p. у концесіонера є можливість регулювання тарифів на ЖКП, з огляду на аналіз істотних умов концесійного договору у випадках концесій на ринках, які перебувають у стані природної монополії, що може спричинити різке, не підконтрольне підвищення тарифів. Хоча, при цьому, концесійним договором також буде передбачатись зобов'язання концесіонера отримувати дохід не за рахунок простого підвищення тарифів на свої послуги, а за рахунок впровадження інноваційних, енергоощадних технологій на шляху від виробника до споживача послуг, проте впливати на зазначений процес в рамках діючого законодавства майже не можливо. Окрім того, концесієдавець самостійно обиратиме найбільш прийнятний спосіб розрахунку концесійного платежу. Проте, для можливості визначення його розміру та включення до істотних умов договору, концесієдавцеві необхідно отримати в Мінекономіки значення чистого доходу від реалізації продукції (товарів, робіт, послуг) у сфері господарської діяльності, в якій об'єкт державної/комунальної власності надано в концесію та значення залишкової вартості основних фондів у сфері господарської діяльності, в якій об'єкт державної/комунальної власності надано в концесію і все це за останні три роки, на підставі інформації від Держстату. Крім того, до істотних умов концесійного договору на надання суспільно значимих послуг в умовах природної монополії фактично може бути віднесено дві суперечливі один одному норми, з одного боку зобов'язуюча концесієдавця відшкодувати концесіонеру витрати за концесійним договором, у разі встановлення тарифів нижче тих, які передбачені договором, $з$ другого ж боку надання можливості не виконувати концесіонеру взяті на себе інвестиційні зобов’язання, поки орган державного регулювання цін (тарифів) не затвердить розмір цін (тарифів), передбачений саме договором.

Перспективою подальших розвідок є формування взаємоузгоджених механізмів та інструментів реалізації регіональних програм старого розвитку.

Стаття надійшла до редакції: 02.01.20 


\section{PUBLIC-PRIVATE PARTNERSHIP AS AN IMPORTANT TOOL OF SUSTAINABLE DEVELOPMENT OF TERRITORIES}

Svitlana Khadzhyradieva, doctor of Science in Public Administration, Professor, Department of Public Administration and Public Service, National Academy for Public Administration under the President of Ukraine, Kyiv, Ukraine.

Nataliia Vasylieva, doctor of Science in Public Administration, Professor, Department of Regional Administration, Local SelfGovernment and Urban Management, National Academy for Public Administration under the President of Ukraine, Kyiv, Ukraine.

Oleksandra Vasylieva, doctor of Science in Public Administration, Professor, Department of Public Administration and Public Service, National Academy for Public Administration under the President of Ukraine, Kyiv, Ukraine.

Mariia Kyrtoka, Graduate Student, Department of Public Administration and Public Service, National Academy for Public Administration under the President of Ukraine, Kyiv, Ukraine.

The article points out that since 2015, the international community has been challenged to meet its ambitious goals of achieving the Sustainable Development Goals, as set out in the United Nations' Summit on the Transformation of Our World: A 2030 Agenda for Sustainable Development. Almost all of them imply the need to create or modernize economic and social infrastructure in developing countries, which requires considerable financial resources. However, the budgets of such countries cannot cover the existing financial needs. Therefore, one of the most important tasks of the new Global Sustainable Development Strategy has been to create the conditions for attracting private sector financial resources to build public-private partnership (PPP) infrastructure. It is noted that the main task of public authorities today is to create a favorable environment for doing business, efficient 
use of resource potential, identifying priorities in social, economic and environmental processes and prospects of development of the territorial community, taking into account its needs and interests.

Attention is drawn to the fact that public-private partnerships in the form of concessions are becoming increasingly popular in the world, as this form of interaction between the private and the public partner creates significant added value for both parties. One of the greatest achievements of concessions is that it solves state tasks by private capital, which is considered to be the most cost-effective state. At the same time, the private partner receives long-term financial interest, which allows him to ensure the maximum efficiency of the solution of the task set by the state or the municipality. The expediency of using public-private partnership in forming the tool for sustainable development of territories as an important tool for ensuring sustainable development of territories is substantiated.

Keywords: public-private partnership, public authorities, concession, sustainable development of territories.

\section{Received: 02.01.20}

\section{References}

1. Ofitsiinyi veb-portal Odeskoi miskoi rady [The official web-portal of the Odessa City Council]. omr.gov.ua. Retrieved from https://omr.gov.ua/ [in Ukrainian].

2. Popov, M.S. (2016). Kontsessyia kak pravovaia forma hosudarstvennochastnoho partnerstva: istoryia razvytyia $\mathrm{v}$ zarubezhnykh stranakh [Concession as a legal form of public-private partnership: a history of development in foreign countries]. Trudy hosudarstva y prava Rossyiskoi akademyy nauk - Proceedings of the state and law of the Russian Academy of Sciences, 6 (58), 70-82 [in Russian].

3. Pro kontsesiiu: Zakon Ukrainy [Concession: Law of Ukraine]. (n.d.). zakon.rada.gov.ua. Retrieved from https://zakon.rada.gov.ua/laws/show/15520\#n801 [in Ukrainian].

4. Pro zatverdzhennia Metodyky rozrakhunku kontsesiinykh platezhiv : Postanova Kabinetu Ministriv Ukrainy [On approval of the Methodology for 
calculating concession payments: Resolution of the Cabinet of Ministers of Ukraine]. (n.d.). zakon.rada.gov.ua. Retrieved from https://zakon.rada.gov.ua/ laws/show/639-2000-\%D0\%BF/card2\#Card [in Ukrainian].

5. Prylipko S., Vasylieva O. and Vasylieva N. (2019), Methodology of forming a comprehensive mechanism for public administration of service cooperation development in rural areas of Ukraine. International Journal of Recent Technology and Engineering (IJRTE). Vol. 8, Issue-4S, pp. 152-156. Retrieved from https://www.ijrte.org/download/volume-8-issue-4s/

6. Rekonstruktsiia systemy kanalizuvannia pivdennykh raioniv Odesy yde za hrafikom - vedutsia puskonalahodzhuvalni roboty [Reconstruction of the sewerage system of the southern regions of Odessa goes on schedule commissioning works are underway]. Ofitsiinyi sait Odeskoi miskoi rady [The official site of the Odessa City Council]. old.omr.gov.ua. Retrieved from http:// old.omr.gov.ua/ua/news/64682/ [in Ukrainian].

7. Vasylieva, N.V. \& Vasylieva, O.I. (2018). Kontseptualni zasady staloho rozvytku terytorialnykh hromad [Conceptual principles for sustainable development of territorial communities]. Investytsii: praktyka ta dosvid Investment: practice and experience, 8, 74-78 [in Ukrainian].

8. Yemelyanov V. M. (2012). Rozvytok partnerskykh vidnosyn biznesu i vlady v systemi derzhavnoho upravlinnia stalym rozvytkom Ukrainy: teoriia, metodolohiia, praktyka [Development of business-government partnerships in the system of public administration in Ukraine's sustainable development: theory, methodology, practice]. Mykolaiv : Yemelyanova T. V., [in Ukrainian].

\section{Відомості про авторів / Information about the Authors}

Хаджирадєва Світлана Констянтинівна: Національна академія державного управління при Президентові України, вул. Антона Цедіка, 20 м. Київ, 03057, Україна.

Svitlana Khadzhyradieva: National Academy for Public Administration under the President of Ukraine, 20, Anton Tsedyk St., Kyiv, 03057, Ukraine.

ORCID. ORG./0000-0002-2256-2579 


\section{E-mail: sententia.hsk@gmail.com}

Васильєва Наталія Вікторівна: Національна академія державного управління при Президентові України, вул. Антона Цедіка, 20 м. Київ, 03057, Україна.

Nataliia Vasylieva, National Academy for Public Administration under the President of Ukraine, 20, Anton Tsedyk St., Kyiv, 03057, Ukraine.

\section{ORCID. ORG./0000-0002-3128-7767}

\section{E-mail: sententia.hsk@gmail.com}

Васильєва Олександра Іллівна: Національна академія державного управління при Президентові України, вул. Антона Цедіка, 20 м. Київ, 03057, Україна.

Oleksandra Vasylieva: National Academy for Public Administration under the President of Ukraine, 20, Anton Tsedyk St., Kyiv, 03057, Ukraine.

\section{ORCID. ORG./0000-0003-1812-4557}

\section{E-mail: sandra_nadu@ukr.net}

Киртока Марія: Національна академія державного управління при Президентові України, вул. Антона Цедіка, 20 м. Київ, 03057, Україна.

Mariia Kyrtoka, National Academy for Public Administration under the President of Ukraine, 20, Anton Tsedyk St., Kyiv, 03057, Ukraine.

ORCID. ORG./0000-0002-0767-8223

\section{E-mail: sententia.hsk@gmail.com}

